\title{
The Impact of the Economic Crisis on Czech Municipal Expenditures
}

\author{
Pavel Rousek ${ }^{1 *}$ \\ ${ }^{1}$ Institute of Technology and Business, School of Expertness and Valuation, Okružní 517/10, 37001 \\ České Budějovice, Czech Republic
}

\begin{abstract}
The paper focuses on the links between municipal expenditures and the economic crisis (or the economic cycle). The aim is to improve the predictions of municipal expenditures: current expenditures, capital expenditures and total expenditures. Current research shows that the predictions in times of economic growth are relatively good, but in times of economic crisis, models fail. The focus of this paper is the context of the business cycle in order to implement these macroeconomic contexts into predictive models. The tool for achieving this goal is to find strong connections, including time shifts.
\end{abstract}

Key words: prediction, economic crisis, municipal expenditures, planning

\section{Introduction}

Predictions of economic indicators are very important tools for public sector management. Unfortunately, some variables are not predicted with sufficient precision for now. This paper aims to show the link between the economic cycle and municipal expenditures. It should serve to predict the future development of municipal expenditures, which will subsequently serve for better planning in public sector.

\section{Methods and Data}

Conclusions of the paper are based on three-dimensional correlation analysis. The first dimensions are input data, which are the macroeconomic indicators of GDP, unemployment, inflation, the balance of payments, fiscal policy. The second dimension is the output data for which municipal expenditure (current, capital and total) is considered for these purposes. The third matrix dimension consists of time shifts in which input and output data can be affected ( 3 years forwards and 3 years backwards).

\footnotetext{
* Corresponding author: rousek@mail.vstecb.cz
} 


\subsection{Macroeconomic Indicators}

Gross domestic product (GDP) is a sum of what is produced in all sectors of the national economy. The reporting unit is the Czech crown at purchase prices including taxes. In the case of goods and services which are not passed through the market and therefore their purchase price cannot be ascertained, the value is calculated by adding value (sum of compensation to employees and consumption of fixed capital) [1]. Nowcasting of Czech GDP via Dynamic Factor Model (DFM) is introduced [2]. Values of Czech GDP in current prices from 1997 to 2015 are in Table 1.

Table 1. Macroeconomic Indicators of Gross Domestic Product (GDP) [1]

\begin{tabular}{|c|c|c|c|c|}
\hline Year & $\begin{array}{c}\text { GDP } \\
\text { (bn. CZK) }\end{array}$ & $\begin{array}{c}\text { GDP } \\
\text { per Capita } \\
\text { (CZK) }\end{array}$ & $\begin{array}{c}\text { GDP } \\
\text { Growth } \\
\text { (Percent y/y) }\end{array}$ & $\begin{array}{c}\text { GDP } \\
\text { Deflator } \\
\text { (Percent y/y) }\end{array}$ \\
\hline 1997 & 1953,3 & 189575 & $-0,7$ & 8,5 \\
\hline 1998 & 2142,6 & 208120 & $-0,3$ & 10,0 \\
\hline$\ldots$ & $\ldots$ & $\ldots$ & $\ldots$ & $\ldots$ \\
\hline 2013 & 4098,1 & 389900 & $-0,5$ & 1,4 \\
\hline 2014 & 4313,8 & 409870 & 2,7 & 2,5 \\
\hline 2015 & 4554,6 & 432006 & 4,5 & 1,0 \\
\hline
\end{tabular}

Unemployment is another monitored macroeconomic parameter. Employees are considered to be all persons $\dagger$ who develop any remunerated activity for at least 1 hour per week in a permanent, temporary, seasonal and occasional manner [1]. Unemployment is connected to GDP via Okun's law. Czech conditions are analysed [3]. The specific values of unemployment in the Czech Republic are shown in Table 2.

\footnotetext{
${ }^{\dagger}$ Including persons working in their own or family business, professional members of the army and persons in the basic military and civil service, persons on maternity leave who worked before going to work.
} 
Table 2. Macroeconomic Indicators of Labour and Unemployment [1]

\begin{tabular}{|c|c|c|c|}
\hline Year & $\begin{array}{c}\text { General } \\
\text { Unemployment } \\
\text { Rate (Percent) }\end{array}$ & $\begin{array}{c}\text { Long-Term } \\
\text { Unemployment } \\
\text { Rate (Percent) }\end{array}$ & $\begin{array}{c}\text { Average } \\
\text { Gross } \\
\text { Nominal } \\
\text { Wage } \\
\text { (Percent y/y) }\end{array}$ \\
\hline 1997 & 4,8 & 1,3 & N/A \\
\hline 1998 & 6,5 & 1,9 & N/A \\
\hline$\ldots$ & $\ldots$ & $\ldots$ & $\ldots$ \\
\hline 2013 & 7,0 & 3,0 & $-0,1$ \\
\hline 2014 & 6,1 & 2,7 & 2,9 \\
\hline 2015 & 5,0 & 2,4 & 2,7 \\
\hline
\end{tabular}

Inflation is defined as a rise in the price level in professional literature. It characterizes the rate of depreciation of the currency within a precisely defined time period. The inflation rate is measured by the consumer price index. The development of consumer prices (cost of living) is monitored on consumer baskets based on a set of selected types of goods and services paid by the population. The total number of representatives is about 700 . Industrial producer price indices are applied in the industrial, construction, market and agricultural sectors [1]. The Czech inflation values are presented in Table 3.

Table 3. Macroeconomic Indicators of Price Level and Inflation [1]

\begin{tabular}{|c|c|c|c|c|c|}
\hline \multirow{2}{*}{ Year } & \multirow{2}{*}{$\begin{array}{c}\text { Inflation Rate } \\
\text { (Percent y/y) }\end{array}$} & \multicolumn{4}{|c|}{ Producer Price Index (Percent y/y) } \\
\cline { 3 - 6 } & Industrial & $\begin{array}{c}\text { Construction } \\
\text { Work }\end{array}$ & $\begin{array}{c}\text { Market } \\
\text { Services }\end{array}$ & Agricultural \\
\hline 1997 & 8,5 & 5,0 & 11,3 & 10,8 & N/A \\
\hline 1998 & 10,7 & 4,8 & 9,3 & 8,8 & N/A \\
\hline$\ldots$ & $\ldots$ & $\ldots$ & $\ldots$ & $\ldots$ & $\ldots$ \\
\hline 2013 & 1,4 & 0,8 & $-1,1$ & $-1,5$ & 4,5 \\
\hline 2014 & 0,4 & $-0,8$ & 0,5 & 0,3 & $-3,7$ \\
\hline 2015 & 0,3 & $-3,2$ & 1,2 & 0,0 & $-6,0$ \\
\hline
\end{tabular}

The balance of payment (BoP) records economic transactions of domestic entities (residents) with foreign entities (non-residents) over a certain period of time. The current account includes in particular flows of goods (exports and imports) and services (revenues and expenditures from transport services, tourism and other commercial and non- 
commercial services). The financial account includes transactions relating to the origination, extinction, and change of ownership of the financial assets and liabilities of the government, the banking and corporate sectors and other entities in relation to foreign countries [1]. Some consequences of Czech foreign trade are analysed [4]. Czech export, import and balance of payment are in Table 4 .

Table 4. Macroeconomic Indicators of the Balance of Payment (BoP) [1]

\begin{tabular}{|c|c|c|c|c|c|c|}
\hline Year & $\begin{array}{c}\text { Export } \\
\text { (Percent y/y) }\end{array}$ & $\begin{array}{c}\text { Import } \\
\text { (Percent y/y) }\end{array}$ & $\begin{array}{c}\text { Current } \\
\text { Account } \\
\text { of BoP } \\
\text { (bn. CZK) }\end{array}$ & $\begin{array}{c}\text { Current } \\
\text { Account } \\
\text { of BoP } \\
\text { (Percent } \\
\text { of GDP) }\end{array}$ & $\begin{array}{c}\text { Financial } \\
\text { Account } \\
\text { of BoP } \\
\text { (bn. CZK) }\end{array}$ & $\begin{array}{c}\text { Financial } \\
\text { Account } \\
\text { of BoP } \\
\text { (Percent } \\
\text { of GDP) }\end{array}$ \\
\hline 1997 & 7,6 & 5,9 & $-113,0$ & $-5,8$ & $-90,4$ & $-4,6$ \\
\hline 1998 & 9,7 & 5,5 & $-40,5$ & $-1,9$ & $-31,7$ & $-1,5$ \\
\hline$\ldots$ & $\ldots$ & $\ldots$ & $\ldots$ & $\ldots$ & $\ldots$ & $\ldots$ \\
\hline 2013 & 0,3 & 0,2 & $-21,8$ & $-0,5$ & 68,3 & 1,7 \\
\hline 2014 & 8,6 & 10,0 & 7,9 & 0,2 & 59,4 & 1,5 \\
\hline 2015 & 7,8 & 8,3 & 11,3 & 0,9 & 175,8 & 4,3 \\
\hline
\end{tabular}

The balance of the state budget is the difference between revenues and expenditures of the state budget. The budget ends with a surplus (revenues is higher than expenditures) or a deficit (the difference between revenues and expenditures is negative). The definition of the balance of government budgets is in line with international standards and regulations of the EU institutions. According to the Maastricht criteria, the ratio of the negative balance to GDP should not exceed 3\% [1]. Detailed analysis of budgets is provided [5]. The values of the Czech state budget and the Czech government budgets are presented in Table 5.

Table 5. Macroeconomic Indicators of Fiscal Policy [1]

\begin{tabular}{|c|c|c|c|c|}
\hline Year & $\begin{array}{c}\text { Balance of } \\
\text { Government Budgets } \\
\text { (bn. CZK) }\end{array}$ & $\begin{array}{c}\text { Balance of } \\
\text { Government Budgets } \\
\text { (Percent of GDP) }\end{array}$ & $\begin{array}{c}\text { Balance of } \\
\text { the State Budget } \\
\text { (bn. CZK) }\end{array}$ & $\begin{array}{c}\text { Balance of } \\
\text { the State Budget } \\
\text { (Percent of GDP) }\end{array}$ \\
\hline 1997 & $-68,2$ & $-3,5$ & $-15,7$ & $-0,8$ \\
\hline 1998 & $-99,5$ & $-4,6$ & $-29,3$ & $-1,4$ \\
\hline$\ldots$ & $\ldots$ & $\ldots$ & $\ldots$ & $\ldots$ \\
\hline 2013 & $-51,1$ & $-1,2$ & $-81,3$ & $-2,0$ \\
\hline 2014 & $-83,1$ & $-1,9$ & $-77,8$ & $-1,8$ \\
\hline 2015 & $-28,6$ & $-0,6$ & $-62,8$ & $-1,4$ \\
\hline
\end{tabular}




\subsection{Municipal Indicators}

Current expenditures are funds spent for operation without long-term benefit, they are classified in the 5th-grade of the budget composition. Czech data of current expenditures are in Table 6. Current expenditures are for non-investment expenditure excluding budget transfers [6].

Table 6. Current Municipal Expenditures [7-9]

\begin{tabular}{|c|c|c|c|}
\hline Year & $\begin{array}{c}\text { Current Expenditures } \\
\text { (bn. CZK) }\end{array}$ & $\begin{array}{c}\text { Current Expenditures } \\
\text { (Percent y/y) }\end{array}$ & $\begin{array}{c}\text { Current Expenditures } \\
\text { (Percent of GDP) }\end{array}$ \\
\hline 2000 & 553,3 & N/A & 23,3 \\
\hline 2001 & 482,9 & $-12,7$ & 18,8 \\
\hline$\ldots$ & $\ldots$ & $\ldots$ & $\ldots$ \\
\hline 2010 & 423,9 & $-10,1$ & 10,7 \\
\hline 2011 & 400,0 & $-5,6$ & 9,9 \\
\hline 2012 & 349,6 & $-12,6$ & 8,6 \\
\hline
\end{tabular}

Capital expenditures (Table 7) are classified into the 6th-grade budget line. Capital expenditures are different kinds of long-term investments such as investment purchases and related expenses, purchases of shares and pecuniary interests, and deposits in foundations and institutions, investment transfers and investment lent [6].

Table 7. Capital Municipal Expenditures [7-9]

\begin{tabular}{|c|c|c|c|}
\hline Year & $\begin{array}{c}\text { Capital Expenditures } \\
\text { (bn. CZK) }\end{array}$ & $\begin{array}{c}\text { Capital Expenditures } \\
\text { (Percent y/y) }\end{array}$ & $\begin{array}{c}\text { Capital Expenditures } \\
\text { (Percent of GDP) }\end{array}$ \\
\hline 2000 & 55,0 & N/A & 2,3 \\
\hline 2001 & 64,1 & 16,7 & 2,5 \\
\hline$\ldots$ & $\ldots$ & $\ldots$ & $\ldots$ \\
\hline 2010 & 87,7 & $-3,4$ & 2,2 \\
\hline 2011 & 75,8 & $-13,6$ & 1,9 \\
\hline 2012 & 67,4 & $-11,0$ & 1,7 \\
\hline
\end{tabular}

Total expenditures to be seen in Table 8 are the sum of current and capital expenditures. 
Table 8. Total Municipal Expenditures [7-9]

\begin{tabular}{|c|c|c|c|}
\hline Year & $\begin{array}{c}\text { Total Expenditures } \\
\text { (bn. CZK) }\end{array}$ & $\begin{array}{c}\text { Total Expenditures } \\
\text { (Percent y/y) }\end{array}$ & $\begin{array}{c}\text { Total Expenditures } \\
\text { (Percent of GDP) }\end{array}$ \\
\hline 2000 & 608,2 & N/A & 25,6 \\
\hline 2001 & 547,0 & $-10,1$ & 21,3 \\
\hline$\ldots$ & $\ldots$ & $\ldots$ & $\ldots$ \\
\hline 2010 & 511,6 & $-9,0$ & 12,9 \\
\hline 2011 & 475,8 & $-7,0$ & 11,8 \\
\hline 2012 & 417,0 & $-12,4$ & 10,3 \\
\hline
\end{tabular}

\section{Results and Discussion}

\subsection{Correlation Analysis without the Time Factor}

Correlation analysis without the time factor means that the same time periods are correlated.

\subsubsection{Current Expenditures}

The analysis of the correlation of current expenditures shows that the strongest positive dependency exists between the unemployment rate and the share of current expenditure on GDP (0.577). The strongest negative dependence is the share of the financial account $\$$ on GDP and the share of current expenditure on GDP $(-0,733)$.

Substantial negative dependence can also be seen when comparing the absolute amounts of current expenditure with total GDP $(-0.621)$ and GDP per capita $(-0.640)$. This negative dependency means that current expenditure develops opposite the gross domestic product. There is, therefore, a visible influence of fiscal policy that stimulates the economy during the crisis and prevents its overheating at the time of expansion.

Growth rates do not appear to be a good predictor, as the dependence of these indicators only ranges from -0.332 (time development of exports versus time development of current expenditures) and 0.536 (time development of price level of market services versus time development of current expenditure).

\subsubsection{Capital Expenditures}

In the case of capital expenditures and investments, the strongest correlation is to total GDP (0.667) and GDP per capita (0.671). In this case (unlike current expenditures) this is a positive correlation. This means that in times of economic prosperity there are enough financial resources for long-term investments.

\footnotetext{
* Financial account of the balance of payment.
} 
Similar results are in percentage analysis. There is a positive correlation with the unemployment rate $(0.625)$ and the long-term unemployment rate $(0.600)$ and negative correlation to the current account $(-0.670)$ and financial account $(-0.856)$ of the balance of payment.

Even capital expenditures are not predictable based on growth parameters (GDP growth, GDP deflator, wage growth, inflation rate, price indexes, export growth and import growth). The only two significant parameters are producer price index of market services $(0.621)$ and agricultural producer price index $(-0.686)$. However, there are no logical reasons for these dependencies.

\subsubsection{Total Expenditures}

The total sum of Czech municipal expenditures is composed of $83-91 \%$ current expenditures and $9-17 \%$ capital expenditures. Therefore, we can expect similar developments and similar correlations as dominant current (operating) expenditures.

There are some strong negative correlations:

- The share of municipal expenditures on GDP vs. Share of the financial account of the balance of payment on GDP $=-0.755$;

- The share of municipal expenditures on GDP vs. Share of the current account of the balance of payment on GDP $=-0.695$;

- There are some substantial positive correlations;

- The share of municipal expenditures on GDP vs. General unemployment rate = 0.591 ;

- The share of municipal expenditures on GDP vs. Long-term unemployment rate = 0.564 .

The above results show that ratios are the most appropriate form of prediction variables because other types of variables show worse values. For example, absolute indicators in Czech crowns correlate negative (from -0.304 to -0.551 ) and percent changes in time correlate very weakly (from -0.337 to 0.582 ). As stated above, total expenditure can be predicted similarly to current expenditure.

\subsection{Correlation Analysis with the Time Factor}

Correlation analysis with the time factor means that different time periods are correlated, for example, how much the previous year GDP affects analysed years expenditures (1 year). There is 7 analysis made from -3 years' time shift to +3 years' time shift. The overview is in Table 9: 
Table 9. Overview of the Time Shifts

\begin{tabular}{|c|c|c|}
\hline Time shift & $\begin{array}{c}\text { Time Period of } \\
\text { Municipal Expenditures }\end{array}$ & $\begin{array}{c}\text { Time Period of } \\
\text { Macroeconomic Indicator }\end{array}$ \\
\hline-3 years & from 2000 to 2012 & from 1997 to 2009 \\
\hline-2 years & from 2000 to 2012 & from 1998 to 2010 \\
\hline-1 year & from 2000 to 2012 & from 1999 to 2011 \\
\hline 0 years & from 2000 to 2012 & from 2000 to 2012 \\
\hline+1 year & from 2000 to 2012 & from 2001 to 2013 \\
\hline+2 years & from 2000 to 2012 & from 2002 to 2014 \\
\hline+3 years & from 2000 to 2012 & from 2003 to 2015 \\
\hline
\end{tabular}

\subsubsection{Current Expenditures}

The first analysis is focused on current expenditures. Really interesting results are in case of balance of payment correlation. We can see the positive correlation of the past data $(0.200$ to 0.518$)$ and negative correlation of the current and future data $(-0.298$ to -0.637$)$. We can use the financial account of the balance of payment from 2 years ago ( -2 years) to predict future values with an accuracy of 0.518 . Or the current account of the balance of payment from 2 years ago ( -2 years) with an accuracy of 0.501 .

Correlation of GDP and GDP per capita values is negative all the time. However, it is getting stronger and stronger in future correlations. The values are:

$-\quad-0.545$ (GDP) and -0.551 (GDP per capita) in the past ( -2 years);

- -0.621 (GDP) and -0.640 (GDP per capita) in the present ( 0 years' time shift);

- $\quad-840$ (GDP and -0.850 (GDP per capita) in the future ( +3 years).

As mentioned above, there is a visible influence of fiscal policy that stimulates the economy during the crisis and prevents is overheating at the time of expansion. However, this stimulation comes too late, 3 years after the crisis peak. The reason is that information about crisis comes too late. The statistical office can measure the GDP ex-post, 1 or 2 years later. Local authorities and local governments can change future budgets according to this information. So the largest changes of municipal budgets are made 3 years after the economic cycle.

Percentage values are not significant in the past (from -0.422 to 0.552). However, we can follow some connections in the present and in the future. The positive correlation of unemployment rates is getting stronger:

- General unemployment rate in the present ( 0 years' time shift) is 0.577 and 0.642 in the future ( +3 years);

- Long-term unemployment rate in the present ( 0 years' time shift) is 0.550 and 0.825 in the future $(+3$ years).

The negative correlation of changes in the balance of payment is getting stronger as well: 
- Current account share on GDP in the present ( 0 years' time shift) is -0.682 and 0.780 in the future ( +1 year);

- Financial account share on GDP in the present ( 0 years' time shift) is -0.733 and 0.811 in the future $(+2$ years).

Percentage changes in time are not significant at all. The values are around zero, sometimes slightly positive, sometimes slightly negative.

\subsubsection{Capital Expenditures}

Second analysis if focused on capital expenditures. Its connection to GDP is quite strong. Especially the positive correlation between capital expenditures and GDP per capita from 2 years ago ( -2 years). The correlation index is 0.707 , which makes it the best value for future predictions. Total GDP is a good indicator as well. The best value is 0.688 for the same time shift (-2 years). Correlations to the balance of payment are not significant, some of them are slightly positive, some of them slightly negative.

Percentage values give weak results in the past (from -0.424 to 0.388 ). However, we can follow some connections in the present and in the future. There are some positive correlations of unemployment rates:

- General unemployment rate in the present ( 0 years' time shift) is 0.625 ;

- Long-term unemployment rate in the future (+2 years) is 0.695 .

There are some negative correlations of changes in the balance of payment:

- Current account share on GDP in the future (+1 year) is -0.681 ;

- Financial account share on GDP in the future (+1 year) is $-0,869$.

Percentage changes in time are not significant at all. The values are around zero, sometimes slightly positive, sometimes slightly negative.

\subsubsection{Total Expenditures}

The third analysis is focused on total expenditures. Some results are similar to current expenditures because the majority (more than $80 \%$ ) of total expenditures are the current ones. Therefore, the results are similar to the analysis of current expenditures.

The strongest negative correlations:

- The share of municipal expenditures on GDP vs. Share of the financial account of the balance of payment on GDP $(+2$ years $)=-0.816$;

- The share of municipal expenditures on GDP vs. Share of the current account of the balance of payment on GDP $(+1$ year $)=-0.789$.

The strongest positive correlations:

- The share of municipal expenditures on GDP vs. General unemployment rate $(+3$ years $)=0.643$;

- The share of municipal expenditures on GDP vs. Long-term unemployment rate $(+3$ years $)=0.827$.

Based on these time shifted correlations we can see that municipal budgets are reason factors and macroeconomic variables are consequence factors. Based on total municipal budgets we can expect the future development of unemployment and balance of payment.

Other types of variables show worse results for predictions. For example past absolute indicators in Czech crowns correlate from -0.497 to 0.500. Past percent time changes correlate from -0.438 to 0.557 . Future absolute indicators in Czech crowns correlate from 0.405 to -0.782 . And future percent time changes correlate from -0.529 to 0.441 . 


\section{Discussion}

Municipal managers must consider a number of different factors in their decision-making. One of the most important factors is the risk [10]. Another factor specific for public sector is so called budget cycle [11-12]. Some authors are discussing specifics of the public sector, such as its centralization and decentralization [13]. This paper focuses on connections between macroeconomic indicators and municipal budgets. There are macroeconomic causes and macroeconomic consequences in the case of municipal budgets. Main reasons or factors influencing the municipal budgets are in Table 10.

Table 10. Factors Influencing the Municipal Expenditures

\begin{tabular}{|c|c|c|c|}
\hline Factor & Current Expenditures & Capital Expenditures & Total Expenditures \\
\hline Gross Domestic Product & Indirect proportion & Direct proportion & Indirect proportion \\
\hline Balance of Payment & Direct proportion & Indirect proportion & Direct proportion \\
\hline
\end{tabular}

A useful tool to nowcast Czech GDP via Dynamic Factor Model (DFM) introduced Rusnák. He "demonstrated good performance for nowcasting of the expenditure components of Czech GDP" [2]. His framework "might be useful in nowcasting other variables as well" [2].

Main consequences or factors influenced by the municipal budgets are in Table 11 .

Table 11. Factors Influenced by the Municipal Expenditures

\begin{tabular}{|c|c|c|c|}
\hline Factor & Current Expenditures & Capital Expenditures & Total Expenditures \\
\hline Gross Domestic Product & Indirect proportion & Direct proportion & Indirect proportion \\
\hline Unemployment Rate & Direct proportion & Direct proportion & Direct proportion \\
\hline Balance of Payment & Indirect proportion & Indirect proportion & Indirect proportion \\
\hline
\end{tabular}

\section{Conclusion}

This paper revealed a negative dependence between current expenditures and gross domestic product. The cause of this negative dependence is fiscal policy, which is done through current expenditures. Thus, the economy is stimulated during the crisis and it is dampening during the expansion.

The strongest correlation is between current GDP and current spending over 3 years. This three-year delay is due to mechanisms within the public sector and time lags, which are seen as one of the causes of government failures. The time delay is the result of ex-post GDP measurement, administrative processes, decision-making processes, budgeting for future periods, etc.

Furthermore, a positive correlation between capital expenditures and GDP was found. The reason for this is the fact that investments are made only with sufficient funds after ensuring the normal running of the municipality. This situation occurs at a time of economic growth. 
Total expenditures consist mainly of current expenditures, so the prediction mechanism of their development is almost identical to current expenditures. The aforementioned negative correlation with GDP and the three-year delay can be applied.

Similar analysis is done in the paper Determinants of Employment and GDP Resilience in the Context of an Economic Crisis [14].

\section{References}

1. Czech Statistical Office, Main Macroeconomic Indicators [online], Available at: www.czso.cz (2017)

2. M. Rusnák, Nowcasting Czech GDP in real time, Economic Modelling. 54, 26-39 (2016)

3. E. Mielcova, Economic Growth and Unemployment Rate of the Transition Country The Case of the Czech Republic 1996-2009. Ekonomie a Management, 14, 29-37 (2011)

4. P. Rousek, Mutual Foreign Trade between China and the Visegrad Group. Littera Scripta, 9, 42-51 (2016)

5. P. Dvořák, Veřejné finance, fiskální nerovnováha a finanční krize, 1. Vyd. Praha: C. H. Beck, 343 s. (2008)

6. Ministry of Finance of the Czech Republic, Decree of the Ministry of Finance No, 323/2002 Coll. of 2 July 2002 on the budget structure [online], Available at: http://www.mfcr.cz/cs/legislativa/legislativni-dokumenty/2002/vyhlaska-c-323-2002$\underline{\mathrm{sb}-3461}$ (2002)

7. Ministry of Finance of the Czech Republic, ARIS web [online], Available at: http://www.mfcr.cz/cs/o-ministerstvu/informacni-systemy/arisweb (2017)

8. Ministry of Finance of the Czech Republic,ÚUIS [online], Available at: http://www.mfcr.cz/cs/o-ministerstvu/informacni-systemy/ufis (2017)

9. Ministry of Finance of the Czech Republic, MONITOR - Information Portal of Ministry of Finance [online], Available at: http://www.mfcr.cz/cs/oministerstvu/informacni-systemy/iissp--monitor (2017)

10. H. Elsawah, I. Bakry, O. Moselhi, Decision Support Model for Integrated Risk Assessment and Prioritization of Intervention Plans of Municipal Infrastructure. Journal of Pipeline Systems Engineering and Practice, 7(4) (2016)

11. T. Aronsson, D. Granlund, Federal subsidization of state expenditure to reduce political budget cycles. International Tax and Public Finance.,24, 536-545 (2017)

12. L. Matějová, M. Plaček, F. Ochrana, M. Půček, M. Křápek., Political Business Cycle in Local Government. Case Study of Czech Municipalities. Current Trends in Public Sector Research, 19, 142-148 (2015)

13. N. K. Hlepas, Is it the twilight of decentralization? Testing the limits of functional reforms in the era of austerity, International Review of Administrative Sciences, 82, 273-290 (2016)

14. O. Svoboda, P Applová, Determinants of Employment and GDP Resilience in the Context of an Economic Crisis: Evidence from EU Countries and Regions. Littera Scripta. 9(2), 140-155 (2016) 
